\title{
PSYCHOLOGICAL AND LINGUISTIC MEANS OF FORMING "A SOVIET PERSON" IN THE JOURNAL PERIODICALS OF THE UKRAINIAN SOVIET SOCIALIST REPUBLIC
}

\author{
Yurij Kolisnyk ${ }^{7}$
}

\begin{abstract}
The article deals with the psychological and linguistic methods of establishing a social life and the impact of the magazines on the public consciousness in the Ukrainian Soviet Socialist Republic. Press provided concealed manipulation programming of the citizens' behaviour. The whole society was imposed with the regulated values, moral imperatives and ideals via indoctrination, pressure and attack. Mass zombing was considerably played by "the new language" which implemented the basic notions of the totalitarian ideology.

Transforming of citizens' consciousness was possible by manipulating with their interests and desires. In this way the run of social processes was regulated. Russification, denationalization and destroying of national memory took place. Having no alternative a person was transformed into a system cog. Thus the aim of the article is to specify the influence of the journal periodicals in 19501980s by psycho-linguistic means on forming the necessary concept of "a Soviet person".

The following methods were used: concrete historical and sociological press analysis, systematic and comparative analysis as well as generalization of contents and subjects of the magazines, analysis of political impact factors on magazines transformation as the mean of forming public consciousness, content analysis for stating the level of ideological partiality in the magazines and the frequency of usage of the ideological words in magazine texts and peculiarity of their combinability. Content analysis indicators are received by calculation on the sectional observation material. The basis of the empirical research is four public-political magazines "Ukrayina" ("Ukraine"), "Vitchyzna" ("Motherland"), "Zhovten"' ("October"), "Radyans'ka Zhinka" ("Soviet Woman") and two children's magazines "Barvinok" ("Periwinkle") and "Malyatko"2 ("Baby") of the 1950-1980s.
\end{abstract}

Keywords: Communist society, Marxist-Leninist ideology, totalitarian journalism, manipulative influence, consciousness formation.

\footnotetext{
Ph. D. in Social Communications, Professor of Bokhdan Khmelnytsky Chercassy National University, Chercassy, Ukraine

2 In this article the interpretation of "ideological partiality of the magazine periodicals" influenced the formation of the public consciousness (giving preferences to communist values, implantation of ideologemes and outlook orientations).
} 


\section{Introduction}

Researches on the totalitarian press and its meaning in forming citizens' communist consciousness prove that there was not only political dependence of the soviet mass media, but also subordination and censoring at all levels of the material preparation. A considerable role in upbringing of "a new person" was played by the concealed manipulation like pressure, attack, indoctrination etc. - implementation of the basic notions of the totalitarian ideology into lexis. Expressing the party will and interests of the communist nomenclature by cultivating a slave's psychology under the slogans of "loyalty to the people's interests" or "serving the Motherland" was widely used by the journalists. The political new language consisted of automatized language phrases, concepts and clichéd thoughts.

\section{Language as a Mean of Impact}

Along with establishing of the soviet periodicals an inseparable process of "...quasicommunication, spreading of "poster" images stereotypes, thematical, lingual, compositional phrases, and impoverishment of the language..." appreared [Potyatynyk, 1991, p. 29]. The press researcher Iryna Herman asserts that at the dawn of the soviet power the press of the Ukrainian Soviet Socialist Republic rarely used the words "mercy, wisdom, joy, good, compassion, love and pietism, also a different stylistical colouring was attributed to the words such as God, Bible, faith, church, religion" [Herman]. By linguistic means totalitarian regime implanted russification, destroyed the national ideals and cultivated the obedience.

Soviet mass media as a communication means of inoculation of marx-lenin ideology to the society, besides the hierarchy of unidirectionality of the information transmission "from top - to bottom", were also characterized by a deep informational limitation and dominance of the ideological doctrine. That is why there was little freedom in the totalitarian journalism. The author of this paper researched the level of ideological partiality ${ }^{3}$ of the magazine periodicals of the Ukrainian Soviet Socialist Republic in 1950-1980s on the basis of six issues - children's magazines "Barvinok" ("Periwinkle") and "Malyatko" ("Baby"), public-political journals "Vitchyzna" ("Motherland") and "Zhovten"' ("October"), as well as magazines "Ukrayina" ("Ukraine") and "Radyans'ka Zhinka" ("Soviet Woman"). The term "ideological partiality" means range of ideological surroundings in the concrete historical period. The content-analysis method was used including formation of optional range, data calculation, generalization of indications and diagrams building for visualization of the obtained results.

The obtained generalized results are presented on a graph of the ideological partiality level of the magazine periodicals in the Ukrainian Soviet Socialist Republic (picture 1).

These data prove the hypothesis that the magazine press of the first years during the post-Stalin period under the guidance of the Communist Party of the Soviet Union had ideological burden for a long time. The indications are so high that even the mean percent of the ideological mark in the period of "liberalization" $(62,0 \%)$ is actually identical to that of the "stagnation" period (62,4\%). Data similarity can be explained on the one hand by the inertial high level of the ideologically marked press at the beginning of the post-Stalin epoch (period of the inner party struggle for power between Molotov, Malenkov, Kaganovich and Khrushchev), but on the other hand - by lessening of ideological filling of the periodicals at the end of 70 s under the conditions of economic decrease and citizens' welfare worsening [Kolisnyk, 2006, p. 228].

The magazine "Baby" was organized later than the initial chronological limit of the research, therefore its part in the content-analysis is taken into consideration since 1960 (the time of foundation). 
Picture 1. The mean of ideological partiality of the magazine periodicals in the Ukrainian Soviet Socialist Republic in 1953 - 1980s (in percent)

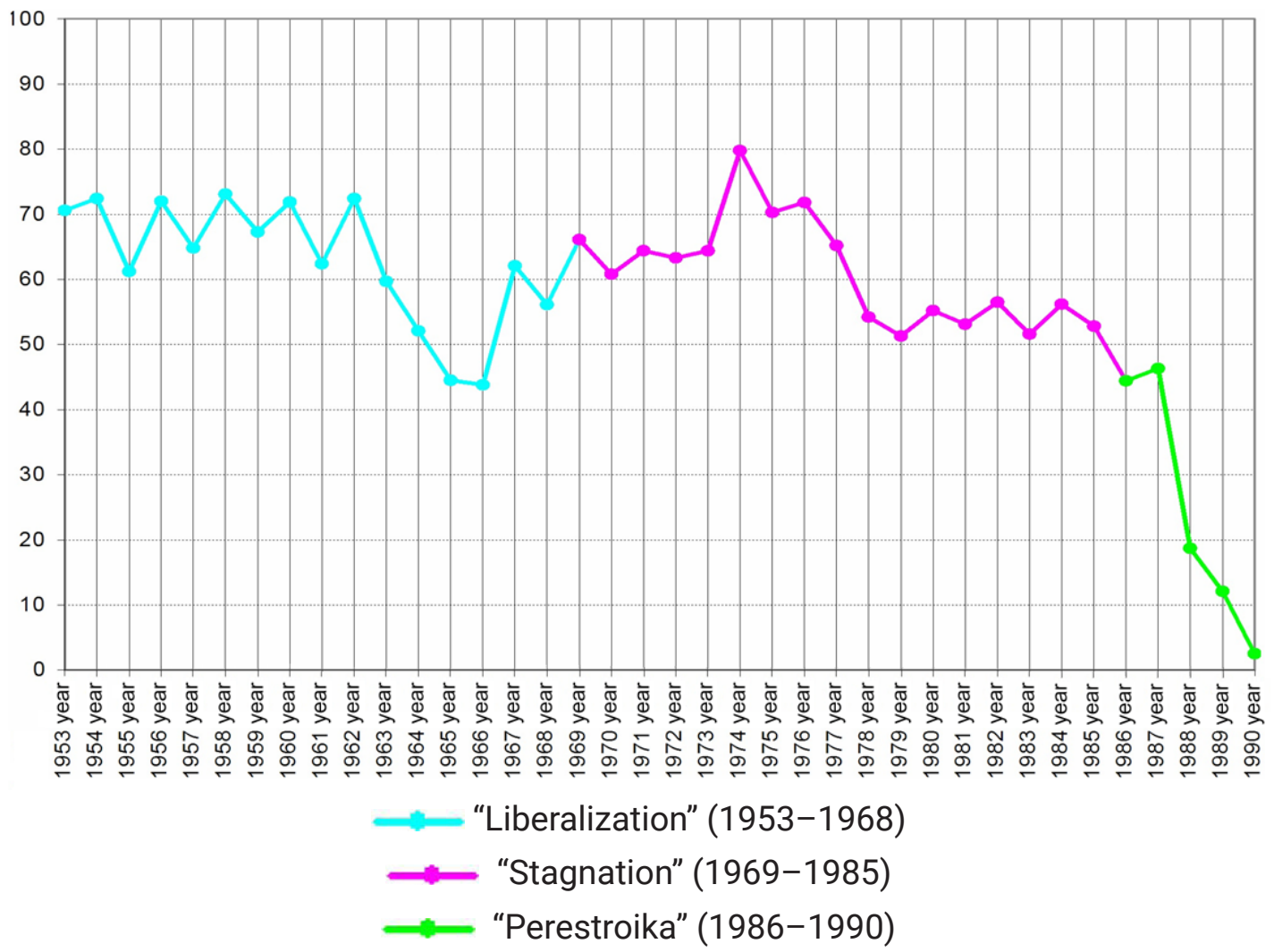

It is considered that Nikita Khrushchev's reform movement and Petro Shelest's activity were the reasons of the sudden lessening of the party propaganda in press during 1962 - 1966. The latter was the first secretary of the Central Committee of the Communist Party of Ukraine (CPU), who deepened the initiated liberalization. His Ukraine supporting policy promoted the press humanization, printing increase and the spectrum of the discussed problems. The following numbers brightly illustrate the quantity of the Ukrainian editions: at the beginning of 1962 there were 105 magazines and magazine type editions in the Ukrainian Soviet Socialist Republic, their general pressrun was 2509 000 issues [Moskovichi, 1998, p. 470].

The popularization of the labour achievements, narration on the corn harvests, etc. on the pages of the magazines was gradually replaced by the researches on the cossacs times, activity of the Ukrainian science and culture representatives and the problems of the native language preservation. Under the Kremlin pressure Shelest's plans on ukrainization were destroyed, still his political activity played a considerable role in the democratization of the cultural and spiritual life in Ukraine including the magazine periodicals.

Soviet journalism as Communist Party interests expresser quickly reacted to the changes of the party's policy and made priorities according to them. The press did not write about the troops invasion of the Warsaw agreement countries to Prague; however the 1968 Prague events were connected with the cease of liberalization not only in Czechoslovakia, but in all post-soviet space. It is proved by a number of party resolutions of that period: "On the increasing role of the district newspapers in the communist upbringing of the labour people" (1968), "On elucidation of the problems of social contest in the press of the Lithuanian Soviet Socialist Republic"(1973), "On the literature and art activity" (1973), "On the improvement of the journalist staff training and after graduate training" (1975) etc.

After the destruction of the communist building and worsening of the foreign policy situation the literature representatives were obliged to strictly follow the party line, to 
reorient on the building of "the developed socialism", to popularize the party role and to glorify the communist leaders. For strengthening the soviet system which had already made a political crevice they headed on Russification, destruction of the national identity and "merging of nations". It was done by the new manager of the Central Committee (CC) of the CPU, Vladimir Shcherbitskiy with his political team consisting of: secretary of the CC of the CPU on ideological issues Valentin Malanchuk and head of the State Security Committee of the Ukrainian Soviet Socialist Republic and party nomenclature Vitalij Fedorchuk, who implemented it into life. Such political changes considerably influenced the level of the ideological partiality of the soviet press, namely magazine editions which is proved by the proposed graph in the first picture. The peak of the ideological dominance according to the analysis falls during $1973-1977$.

Censorship control and political persecution deeply marked the public consciousness. Assistance in russification, as well as disparaging of Ukrainian culture and history did not help Shcherbytskiy to gain a position in the Kremlin. To raise his authority in Ukraine, he decreased assimilation pressure at the end of the 1970s. It also had its impact on the level of ideological partiality of the magazine mass media, which is illustrated in the graph.

Multiple incompletion of economic tasks of the five-year plans, failure of the Food Programme, country devastation via arms race, and collapse of the world oil prices made Mikhail Gorbachev's government undertake political reforms. The causes of the country's falling down into the economic abyss were linked with the party nomenclature's breaking with "Lenin's norms" that led to "deformation of the socialism". Gorbachev saw the way out of the situation in perestroika i.e. "democratization of all life sides of the Soviet society" [Materials, 1986, p. 139]. The means of the aim achievement became the policy of publicity. It not only stopped persecution of the dissidents, but also caused decreasing of party state pressure, and removal of censorship restriction. Since 1987 the imprisoning "for word" stopped.

In 1990 at the February plenary meeting of the CC of the Communist Party of the Soviet Union (CPSU) Article number 6 on the leading role of the party from the Constitution of the Soviet Union was taken away. The processes became irreversible. Pluralism, publicity, democratization as well as total crisis of the political system influenced the quick cut down of the ideological partiality in the soviet mass media, including magazines. The results of the content analysis prove (see picture 1) that the mean level of the magazines partiality in "the perestroika" period is $25,3 \%$ with a descending tendency.

Calculations are done according to the formulae for calculating standard and boundary errors with unrepeated stratified (according to the names and historic periods) selection:

$$
\begin{gathered}
\mu=\sqrt{\frac{\overline{W(1-W)}}{n}\left(1-\frac{n}{N}\right)},(1.1) \\
\Delta=t \mu=t \sqrt{\frac{W(1-W)}{n}\left(1-\frac{n}{N}\right)},
\end{gathered}
$$

where $\mu$ and $\Delta$ - correspondingly - are standard (mean) and boundary errors of representation; $t$ - is a coefficient of credit (according to the meanings in the table of the integral function, made by Laplas, $F(t)$ credential probability $95,0 \%$ corresponds to $t=1,96) ; W$ - is a selectional esteem of the ideological partiality level in the magazine periodicals (the mean of the ideologically partial area); $(1-W)$ - the mean of the impartial area; $\overline{W(1-W)}$ - is the mean of the group (editions according to the names within the period limits, periods) dispersions; $n$ - is the range of the factual (empirical) selectional 
totality; $N$ - range of the general totality.

Thus, in general totality in $95 \%$ cases the level of the ideological partiality in the magazine periodicals according to the conducted selected examination comprises the limits: the period of "liberalization" - from 56,25 to $67,75 \%$; the period of "stagnation" from 57,48 to $67,32 \%$; the period of "perestroika" - from 19,75 to $30,85 \%$; in total - from 50,35 to $56,65 \%$.

Diagrams of dividing the part of the ideological partiality in the magazines "Barvinok", "Malyatko", "Vitchyzna", "Zhovten"', "Ukrayina" and "Radyanska Zhinka" and their constituents for the three socio-historical periods are built (picture 2).

Picture 2. Ideological constituents of the magazine press of the Ukrainian Soviet Socialist Republic in 1950 - 1980s (in percent)

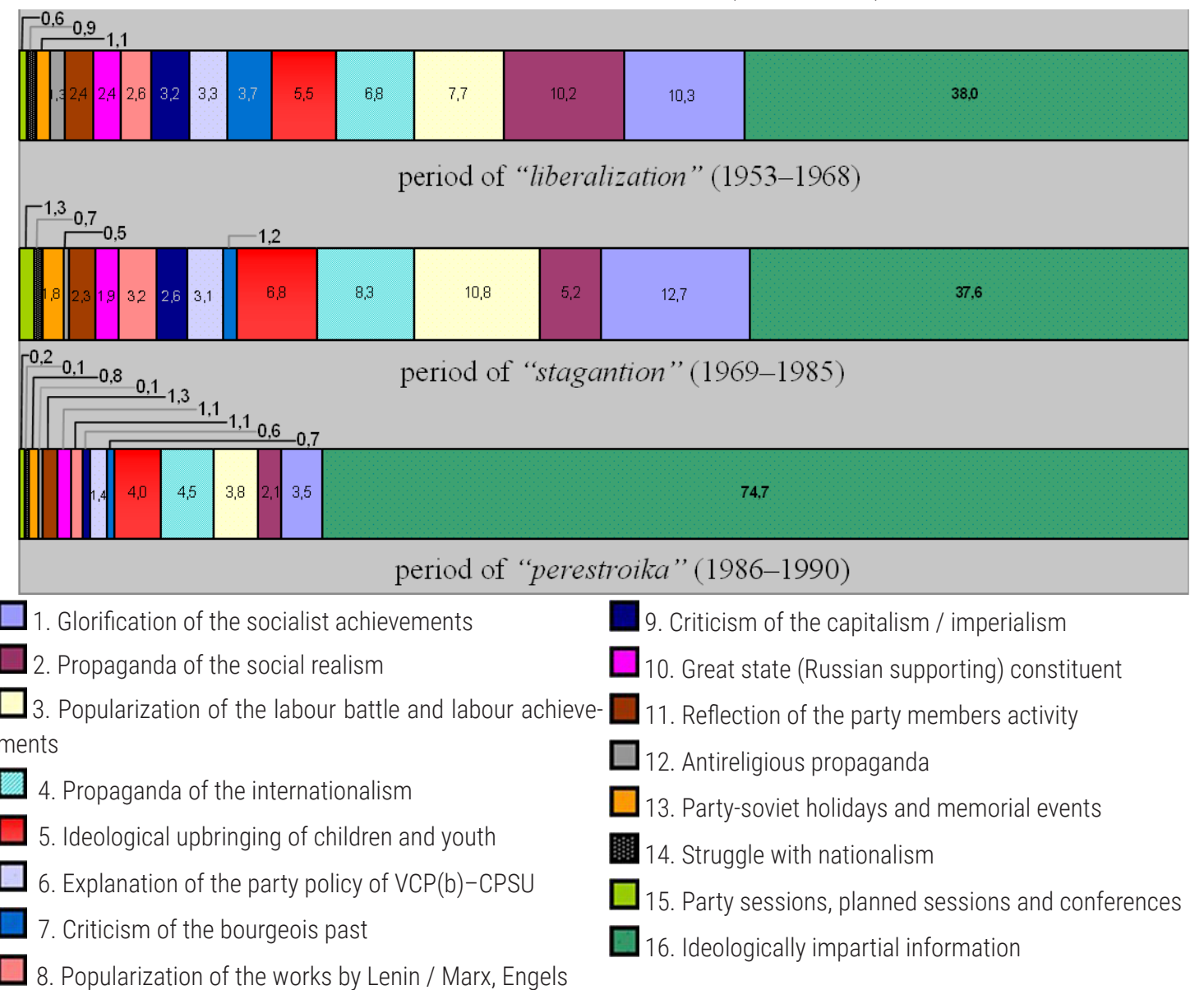

As it can be seen from the diagrams the main activity of the magazine editions in the Ukrainian Soviet Socialist Republic of the researched period was glorification of the socialist achievements. In the conditions of "liberalization" it was $10,3 \%$ of the total area, "stagnation" - 12,7\%, "perestroika" - 3,5\%. Elucidation of the Soviet achievements was often converted into similar rubrics - popularization of battle and labour achievements (narrations on war and labour veterans) - in the period of "liberalization" - 7,7\%, "stagnation" - 10,8 \%, "perestroika" - 3,8\%. When it comes to the propaganda of social realism, its quantity in the period of "liberalization" ranges over $10 \%$ of the area. The basis of those themes is made up by literature and art articles, connected with the struggle for establishing socialist society.

The Soviet press played a great role in the upbringing of the young generation in the spirit of Marx-Lenin and loyalty to the party. Ideological upbringing of the children and the youth on the pages of the magazine periodicals comprised correspondently 5,5\%, 6,8 \% and $4,0 \%$ in different time intervals. On the background of the relatively low ideological partiality of editions in the epoch of "perestroika" (25,3\%) four percent is a considerable 
indication. Under the conditions of the deep social and political crisis party relied just on the youth, which is clearly seen in further research results [Kolisnyk, 2010, p. 60].

An important element of the magazine mass media ideological entourage is great state (Russia supporting) constituent - Moscow centrism. Constant advances to Russia, endless appeals to Moscow, as well as references to Russian scientists, writers and composers are characteristic of the press of the Soviet Socialist Republic in various periods - correspondently 2,4 \%, 1,9\% and 1,1\%. Children's magazines "Barvinok" and "Malyatko" constantly mentioned the Kremlin, the Red square, Moscow (sometimes more often than Khreshchatyk and Kyiv), overused translations from Russian etc. Editions for adults did the same, especially if there was a necessity to assert something or make reference to the authority. Magazine mass media did not distract their attention from internationalism which was a unity prerequisite of the Soviet Union. Propaganda of it did not stop for long. The period of "liberalization" contains 6,8 \%, "stagnation" - 8,3\%, "perestroika" $-4,5 \%$ of the magazine area. Themes of the internationalism were often close to similar fields, namely cultural enrichment and international cooperation which is surely positive. Still there was a number of misuses in this sphere like transition of internationalism in an aggressive struggle with capitalism, opposition of "the dark" past to the bright future etc.

Analyzing a wide spectrum of the Soviet propaganda in the magazine mass media the author also pays attention to other constituents of the communist ideology like elucidation of VCP(b)-CPSU policy, propaganda of achievements by Lenin / Marx and Engels, description of the party representatives' activity, celebration of the party-Soviet holidays and memorable events, holding party planned sessions and conferences, criticism of the bourgeois past, criticism of capitalism / imperialism, antireligious propaganda, struggle with "nationalism" etc. They all take an important place in the magazine press.

Periodical editions were the hostages of the totalitarian system for a long time. Implanting one and the same set of axioms, notions, ideas, esteems and blocks of judgments and dominating ideology not only denied alternative views, but also was a powerful manipulating means. The methods of the constant set phrases were an efficient mechanism in forming public consciousness.

Soviet political system strengthened and reflected itself due to the branched system of means, which was crystallized during the years, improved and with small changes continued to act, to influence the masses, to organize them and to form their consciousness. Among the most important constituents of this system was upbringing of the so called "new person, a builder of the communism, faithful to Lenin and Communist Party's work". For routing out the given task, the mass media were widely used aiming at different layers of the citizens. Soviet ideological institutions tried to make a person ideologically partial, and to completely deepen him or her in the political myths creation. Even without sharing the propagated ideologemes completely, a person "got their infection" to some extent, becoming "a soviet person" (homo soveticus).

Upbringing of the growing generation, labour people, scientists, intelligence, workers and peasants was done under the conditions of one-dimension, one-pole, the only ideology and monoculture. It was like programming of beliefs, ideological statements, masses' moral aims, their spiritual needs and even psychological states. To conceal the total all-state manipulation of the consciousness, the aimed zombing of public was covered by the humanistic term "upbringing of the masses".

A lot of factors show the essence of the Soviet moral. Firstly, various ideological working out was really aimed at spiritual and psychological impact. Secondly, to reach the success of manipulation they created a false reality, such as: "development of productive forces", "building of the spread socialism", "building of communism", "industrialization", "collectivization", "rebuilding", "cultural revolution", "perestroika" etc. Thirdly, for reaching their goals they used a powerful number of ideological means, namely mass 
media. Manipulation and mastering of the mass consciousness were an inseparable part of the authority's techniques, and the method of the spiritual influence on people via programming their bahaviour. Under the slogans of "all for the sake of a human...", "from everybody according to his/her abilities to everybody for his/her labour", "Party's plans are people's plans", "The Party and the people are united" they realized the planned "social" and "communist" building as well as provided an unnoticeable, "volunteering"and seemingly humane subordination to the human's will. Communist Party of the Soviet Union implanted political strategy via selection of methods and actions which was a guarantee to reach the necessary aims. Psychological influence methods were efficient means of solving strategic tasks.

Manipulating by interests, needs, wishes and intentions mass media transformed the public consciousness. The implanted ideology neutralized life experience, and eliminated ability to critical analysis. Raising the citizens' moral and ethical behaviour norms served an efficient strategy of the state management and powerful means of transforming an individual into "a cog" of the political system. Being informationally captivated a person unwillingly did the programmed actions. In such a way they regulated social and economic, political and ideological, as well as cultural and spiritual processes. Thus, Russification and denationalization were conducted and the national memory was being destroyed meanwhile. People being in non-alternative mass communicative space had too little possibilities for the realized choices. The total informational influence was perceived as objective and the only correct one. Public consciousness was formed on the basis of the political and ideological standards.

\section{Methods of the Mass Influence in the Soviet Press}

According to the concept made by Russian researcher Vladislav Deryugin the system of the psychological impact comprises methods such as: attack, pressure, programming, and manipulation [Denisov, 1998, p. 78].

Psychological attack in journalism is an active verbal influence on the citizens to get their expected reaction.

Psychological pressure in mass media is a stable verbal influence on the human psychic to make him/her do some actions.

Psychological manipulation is a directed influence on the individuals' psychic to choose their behaviour among several alternatives.

Psychological programming is a systematic influence on the human psychic to create an algorithm for his/her intellect and forming behavioural stereotypes.

As for the psychological methods they were widely used in the Soviet journalism. Their practicing coded the mass consciousness and gave an opportunity to reach a political result. The totalitarian press used these methods either separately or as combined with other manipulation means.

Magazine periodicals of the Ukrainian Soviet Socialist Republic used the majority of the manipulating actions, thoroughly described by American researchers, namely psychologist Paul Cugler [Boiko, 2010, p. 165-195]. Among them one can mention the following: "giving labels" to anti-Soviet social phenomena, dissidents and foreign organizations to discredit them, "reference to the authority ", "play in populace", "transfer" - popularization of one's authority / prestige to the one that should be supported (language clichés: "young Leninists", "young Korchaginists", "Lenin's Komsomol”, "children of the October" and others), "method of raising value", "glittering generalizations", "imposure of perception model", "method of evidence", usage of trap-questions for establishing communist ideas, practicing the trap of "permanence of principles", usage of the trap "majority's opinion", tendentious arguments selection, "method of isolation" (clipping an utterance out of the context), avoiding position support, speculating ignorance and conclusion imposture. 
Totalitarian practice of the Soviet mass media is also proved by the methods of political manipulation affecting the mechanisms of psychic regulation. Magazine periodicals of the mentioned years used them very often. Among them one can name the following: appeal to feelings and emotions, "method of a direct attack on an interlocutor", "method of guarantees", "method of social mindset" (involving in mission activity), "method of "the smoke veil" (imitation of regularity), "method of new values / ideals popularization", appeal to "higher interests", proofless statements and "panning". Magazine press of the Ukrainian Soviet Socialist Republic actively used means of political manipulation directed to perception peculiarities such as: "action of erroneous causality", "action of false generalization / exaggeration" and "action of jumping over an event".

There were also the means of demagogy in the totalitarian mass media. The magazine press used them rather often. Another factor of the psychological action was the method connected with the memorizing peculiarity - the last word effect. The majority of articles in the newspaper and magazine press of the Ukrainian Soviet Socialist Republic were finished with the phrases the manipulators used to impose the necessary idea.

Besides psychological means of manipulation, magazine periodicals of the Ukrainian Soviet Socialist Republic also made practice of the procedure impact methods. The most typical of them were the following: keeping silence - presenting truthful but incomplete information, selection - presenting optional material, distortion (unilateral, tendentious elucidation), deformation (change of proportions), tumbling (change of the evaluation categories " + " into " - "), programming of perception and future reaction, method of uniting authoritative and non-authoritative (uncertain) information within one's utterance and limited access to information. The state informational space guidance also played a considerable role in manipulating public consciousness. Soviet censorship did not only use print prohibition or works retrieval. Informational current went through different phases of control, namely self-censorship, check by media-organization, and out-of-editorial office factors like law limitations influencing the material selection.

All those methods are thoroughly described by the author of this article in his thesis and completed with numerous examples of the manipulation influence of the magazine press on the mass consciousness in the Ukrainian Soviet Socialist Republic [Kolisnyk, 2012, p. 163].

The results of the analysis prove that manipulation in the Soviet journalism was widely used for realization of the CPSU main policy and its leaders' plans. A number of emphasized manipulating means were used with that aim. In ideocratic, theocratic and democratic societies there are also many fields of public life, where outer mass subordination is to be replaced by inner, spiritual and invisible consent. It is widely promoted by school, press, electronic mass media etc.

Having prohibited religion and dissension Communist party maximally used its own ideology to widely form and control public opinion. For the journalism the task was easier because people in the process of "thinking economy" tend to follow the ready clichés, concepts and views, narrowing their consciousness for perception of information. Thus, a word gains a special weight in the ideological providence (upbringing).

An influential means of population ideologization was constant spreading of the basic concepts - fundamental maxims of the Marxism-Leninism. The scientist from Ivan Franko National University Olga Fedyk correctly asserts that communist ideology was supported by "the specially designed "vocabulary", artificially compiled in ideological studies, which was characterized by the fact it did not call the things the way it saw them. For example: people's welfare, a new person's beauty, a communism builder's moral codex, radiant future, happy today, successful completion of the five year plan, working people's achievements in building communism, working people's achievements, victorious march of the communism, social goods, happy childhood, working people elated with success, inspired by the party, radiant heights of the communism, people's enthusiasm, party 
loyalty etc. These and other names served to Bolshevik Moscow empire to reflect and nam absolute degradation of the society and a person [Fedyk, 2000, p. 78].

These views are also shared by the Russian linguists Pyotr Denisov and Konstantin Zuyev. Denisov says that the totalitarian language is characterized not only by forcing tone but also by a high frequency, iteration, imposture and implanting axioms of "the new thinking" [Denisov, 1998, p. 76]. Thereby thoughts, language and life itself were filled with stereotypes. Looking deeper into the problem Zuyev summarizes: "Spreading of the communist ideology dogmas in the society happened at the level of subconsciousness... Constant iteration and hyperbolization of the new revolutionary symbols (...) first of all encouraged their automatization and as a result mass application" [Zuyev, 2005, p. 51-52].

These methods were widely used in the magazine periodicals of the Ukrainian Soviet Socialist Republic. Let's illustrate it by the means of content analysis. Based on the issues of the magazines "Barvinok", "Malyatko", "Vitchyzna", "Zhovten", "Ukrayina" and "Radyanska Zhinka" (652 issues in total), selected proportionally by random during the periods, by means of the representative option (the procedure is thoroughly described in the author's thesis) the number of the totalitarian language key ideologemes is counted. To do this task the computer programme "Readiris" is used, which helps to convert the previously made graphical photocopies of the magazine press into the recognized text. Recognition error is $\leq 5 \%$. The obtained text layer was saved in a pdf-format to have the possibility of word search. On the basis of all the data added for every year ideological lexems frequency usage during three various periods ("liberalization", "stagnation", "perestroika") was defined. The obtained results are presented in the form of a diagram (picture 3).

Picture 3. Usage frequency of ideological lexemes in the magazine press of the Ukrainian Soviet Socialist Republic (counting per 1 mln words)

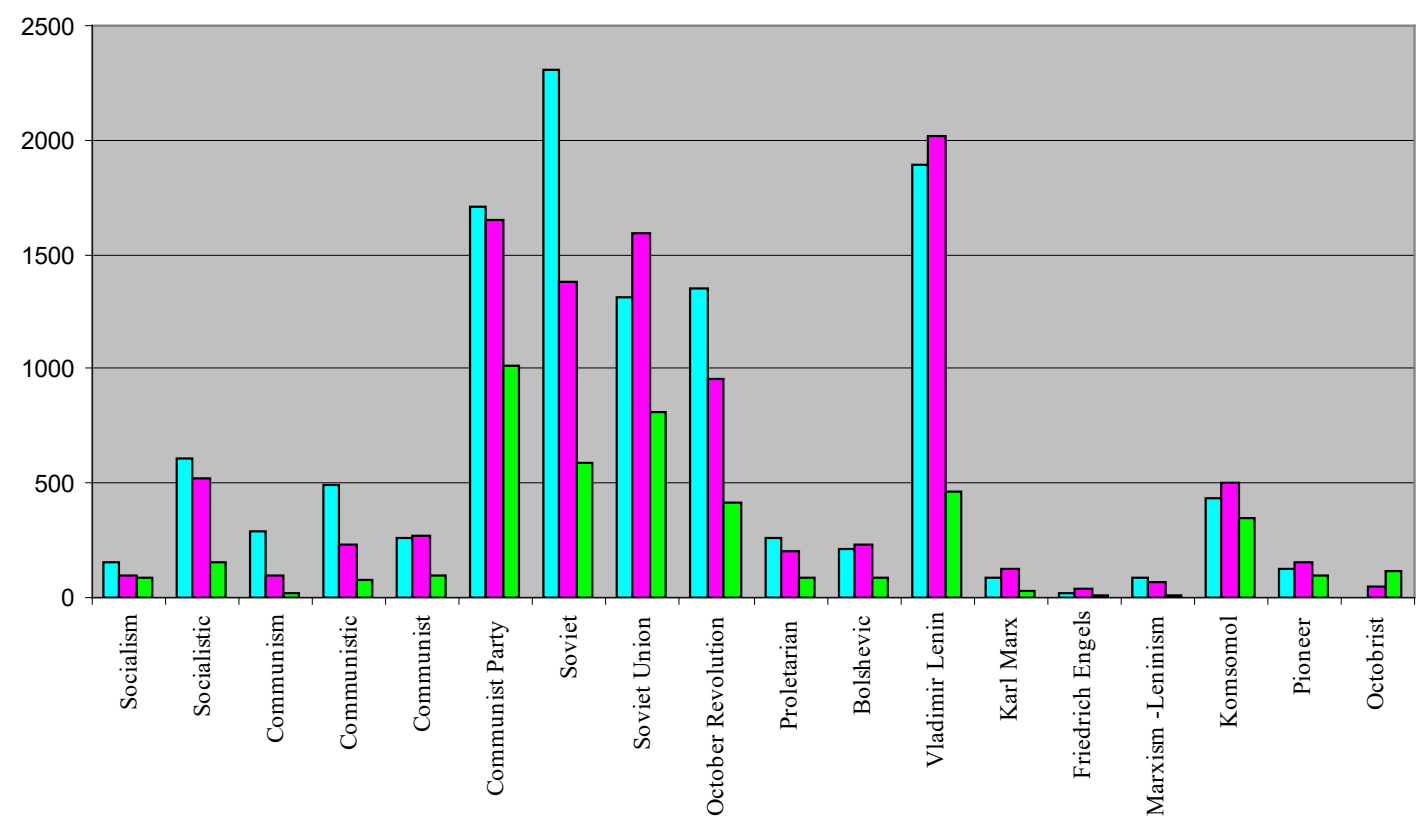

“Liberalization” (1953-1968), $\square$ “Stagnation” (1969-1985), $\square$ “Perestroika” (1986-1990)

As it can be seen the most used ideological lexemes are the following: Communist Party/CPSU, Soviet Union/USSR, Country of Advice, Soviet (epoch, people, engineers, writers, composers, inventors etc.), Volodymyr Lenin /Ulianov and Great October Socialist Revolution. The highest level of the utterance stereotypeness is represented in the mag- 
azine press in the period of "liberalization" and "stagnation" (1953-1985s). "Up to that time they have already created a system of norms and principles, which lay in the basis of the language and speech organization - the whole language life of the Soviet society" [Romanenko, 2002, p. 119]. Under the totalitarian conditions people were obliged not only to write, but also to speak and think according to the ideological clichés. Because of some deviation from canons the journalists were persecuted on various levels. Establishment and the support of the political new language were powerful means of forming public consciousness. In constant propaganda of the ideological concepts, phrases and words one could avoid concealed influential means. As the French psychologist Serge Moscowichi asserts repetition is an important mean of propaganda since "it gives additional arguments to the statements and transforms them into obtrusive ideas. By listening to them again in different variations and on different occasions a person absorbs them. They are repeated unnoticeably like currents of language and thoughts. Such repetitions build a strong barrier against alternative statements and proofs " [Moskovichi, 1998, p. 189-190].

Via constant spreading of the political ideologemes (words and syntactical constructions) magazine periodicals drew readers' attention to the key moments. Articles were written in such a way to be perceived emotionally. A long repetition of the political postulates contributed to the implementation of the ideas into action: "by means of repetition a thought was separated from the authors and converted into reality, irrespective to the time, place or personality" [Moskovichi, 1998, p. 191]. By means of calls, statements and repetitions communist ideology filled consciousness and transformed itself into a belief. The author supports the statement by Olga Fedyk that "the essence of lingual hypnosis lies primarily in inadequate reflection of the realities, and also in multiple repetition of one and the same phrases and utterances, which makes a thinking process stereotypical and unifying" [Fedyk, 2000, p. 78].

Party-Soviet mass media actively brought ideological lexis into life. To determine its specification a contextual analysis of the text was used, the lexical word-combinations of the magazine periodicals in the Ukrainian Soviet Socialist Republic became its basis. It will be widely described in the next articles.

Soviet "new language" as a mean of communist ideology transfer had a vertical direction "party - press - people" that is why it was considerably cultic. Totalitarian press widely used new language aimed at social management and citizens' ideological upbringing. Building of "the new society" really meant "atrophying of the society organism, destruction of the master's traditions set over the ages and cultural approach of many nations" [Fedyk, 2000, p. 80].

For manipulative influence the press used means of "semantics and rhetorics " $\mathrm{Ka}$ ra-Murza] and actualized "a new language" in order "to provide outlook and mental activity not only by sign means (...), but also to make other thought directions impossible" [Vovk, 2003, p. 42]. Magazine articles were often supported by the slogans, idioms and ideological clichés etc.

Ukrainian researcher Olga Fedyk correctly admits: "Inadequate nominations made psychological barriers between people and formed false image on the society and a person itself. Communist new language, as it was called by the English writer G. Orwell, coded not only the truth on the reality but also our past. History of Ukraine was completely atrophied and removed of the national consciousness that put away our nation from the spiritual sources, deprived it of its national idea and caused some gaps between generations. As a result an image of Ukraine lost its national and creative face, a nameless part of the great Russia appeared on its basis in the consciousness of many Ukrainians and non-Ukrainians" [Fedyk, 2000, p. 80-81].

As a manipulating mean journalism used also constant glorification of the party and its leaders. Professor of the Yagelon University Lucian Suhanek writes that in Bre- 
zhnev's epoch a leader's cult was especially actualized, thereby it had "non-leader but administrative and bureaucratic character. Simultaneously it was the period of the nomenclature communism; it was at that time when the silence during "the thaw" nomenclature received full power. (...) The world ideological expansion increased contributing to "Soviet mania" and a threat of Stalinism revival appeared" [Suchanek, 2001, p. 495]. As a result, ideological means for zombing citizens' consciousness expanded.

\section{Conclusion}

It is evident that no society can do without mass communication and its manipulative influences. Having made a deep analysis of the USSR magazines of 1950-1980s the great impact of the press on forming a Soviet citizen was proved. The Party-Soviet journalism widely used psychological and linguistic methods for establishing "caserne socialism" and spiritual slavering of people. Printed word became an efficient instrument for ruling the people in the Soviet Union.

The great thinker Plato admitted that manipulation is characteristic for the human essence and it is its inseparable constituent. The main problem lies in whether it is directed to the human benefit or against human essence? For protecting consciousness from pathogenic influence modern researchers advise to widely use dialogue technique in learning informational propositions - public discussion of important issues, which contributes to the revealing of the manipulative aspects. People's ability to conceptually think and realize events and phenomena is necessary for recognizing manipulation mechanisms and avoidance of their negative consequences. Analysis of the magazine mass media in Ukraine of the 1950 - 1980s leads us to such conclusions.

Inevitable time flow and course of historic events gradually eliminate erroneous ideas, giving preference to the true virtue (though it is not easy). It cannot be realized otherwise than by means of "the struggle of all ideas - whether truthful or fraudulent, absurd or clever. Only out of this mixture an ordinary mind with a given human ability to differentiate good and evil learns to choose one idea and remove others" [Robespier, 1906, p. 7-8]. Journalism of the past assures that understanding obtrusiveness but not the providence of the objective realities and society development tendencies is false. That is why modern mass media should create a wide informational space instead of imposing some viewpoint.

\section{References}

BOIKO 0. (2010), Political manipulation : teaching manual. K.: Academy edition. $-432 \mathrm{p}$.

DENISOV P. (1998), Language of the Russian public thought at the end of the XIX - the beginning of the XX centuries. - M. : MALP. - $185 \mathrm{p}$.

DERYUGIN V. (2011), System of psychological impact methods. (n.d.), http://psychology.net.ru/articles/ content/1105305530.html (17.10.2014).

FEDYK 0. (2000), Language as spiritual adequate of world (reality). - Lviv : Missioner, $300 \mathrm{p}$.

HERMAN I. Language and stylistical peculiarities of the periodical press of Zaporizhzha in 1920s: the main ways of improvement literature norms and styles. [in:] Electronic library of Institute of Journalism in KNU. (n.d.), http://journlib.univ.kiev.ua/index.php?act=article\&article=1052 (27.02.2016).

KARA-MURZA S. Manipulation of consciousness. (n.d.), http://lib.meta.ua/book/13171 (14.09.2015).

KOLISNYK Y. (2006) Disinfirmational Fuinction of USSR Press (International Aspect) /Yurij Kolisnyk // Herald of Lviv State University. Journalism. - Lviv: Editorial office of Lviv State University. - Issue 28. p. 225-238.

KOLISNYK Y. (2012) Magazines of Ukrainian Soviet Social Republic in Forming Public Consciousness (thesis). Kyiv, $452 \mathrm{p}$.

KOLISNYK Y. (2010) Magazines of Ukrainian Soviet Social Republic as the Means of the Mass Ideological Upbringing /Yurij Kolisnyk // Journalism: a collection of works. - Kyiv: Institute of journalism of the Taras Shevchenko KNU. - Issue 9 (34). p. 50-63. 
Materials of XXVII session of the Communist Party of the Soviet Union, editor N. Gudkov. - Moscow : Political edition, 1986, $352 \mathrm{p}$.

MOSKOVICHI S. (1998), Age of crowds : historical treatise on mass psychology; translated from French by T. Yemelyanova. - M. : Centre of psychology and psychiatry, $480 \mathrm{p}$.

ORWELL G. 1984 : [novel-antiutopia] (n.d.), http://lib.ru/ORWELL/r1984.txt (01.01.2016).

POTYATYNYK B. (1991), Totalitarian journalism : text of lectures. - Lviv : Editorial office of Lviv State University, $80 \mathrm{p}$.

Press [in:] Ukrainian encyclopedia : in 17 volumes / chief editorial board : M. Bazhan (editor-in-chief) [and others]. - K. : Chief editorial office of The Ukrainian soviet encyclopedia, 1963, Volume 11, P. 470-471.

ROBESPIER M. Speech on press freedom, made in Yacobian club, 11 May 1794 and repeated in National meating 22 August 1794. - M. : Edition of V. Sablin, 1906, $16 \mathrm{p}$.

ROMANENKO A. (2002), Soviet verbal culture: domestiv history of its studying [in:] Questions of Linguistics. - Num. 6, P. 118-139.

SUCHANEK L. (2001) Jurij Druznikov w poszukiwaniach aniołowie / Lucjan Suchanek // Drużnikow J. Anioły na ostrzu igielnym / Jurij Drużnikow. - Krakow : Arcana. - S. 492-500.

VOVK A. (2003), Political myth. [in:] Independent cultural magazine "I". - 2003. - Part 30. - P. 42. (n.d.) http://www.ji.lviv.ua/ n30texts/vovk.htm (09.02.2015).

ZUYEV K. (2005), Ideologization of a language in political, avangard and scientific texts at the beginning of the XX century : thesis applying for assistant professor's degree : 10.02.01. - Stavropol. - $192 \mathrm{p}$. 